\title{
Feminist digital diplomacy and foreign policy change in Sweden
}

\author{
Karin Aggestam ${ }^{1} \cdot$ Annika Bergman Rosamond $^{1} \cdot$ Elsa Hedling $^{1}$ (I)
}

Revised: 8 May 2021 / Accepted: 5 July 2021 / Published online: 30 July 2021

(c) The Author(s) 2021

\begin{abstract}
This article analyses how the launch of Sweden's feminist foreign policy marked a change in Sweden's digital diplomatic efforts. It draws on three strands of research: digital diplomacy, foreign policy analysis (FPA) and feminist scholarship. Informed by FPA, the article explores the relevance of political leadership, bureaucratic agency and political context as drivers of policy change, and, specifically, Sweden's feminist digital diplomacy. The article provides an empirical case analysis of Sweden's foreign policy change and conduct of digital diplomacy during the period 2006-2020. It draws on documents available on the official websites of the Government Offices of Sweden and the Ministry for Foreign Affairs, including sites such as SwedenAbroad and Swedish Foreign Policy Stories. The article concludes that Sweden acted on a window of opportunity in global politics, which advanced a novel feminist digital diplomacy. Sweden's competitive edge was based on a strong transformative political leadership in foreign policy, state feminism and an early engagement of digital diplomatic management of its state image online.
\end{abstract}

Keywords Feminist foreign policy $\cdot$ Feminist digital diplomacy $\cdot$ FPA $\cdot$ Leadership $\cdot$ Foreign policy change $\cdot$ Bureaucratic agency

\section{Introduction}

In 2014, Sweden was the first state in the world to adopt a feminist foreign policy with the distinct goal of becoming "the strongest global voice for gender equality" (Government Offices of Sweden 2015b). The promotion of women's rights and gender equality in global politics is now central to Sweden's foreign policy practice (Aggestam and Bergman Rosamond 2016; Aggestam and Rosamond 2019; Bergman Rosamond 2020; Rosén Sundström and Elgström 2020). This article examines the ways in which Sweden has sought to promote feminist values in foreign policy practice through the conduct of digital diplomacy. More specifically, we analyse how the launch of Sweden's feminist foreign policy marked a change in the country's digital diplomatic efforts.

Elsa Hedling

elsa.hedling@svet.lu.se

Karin Aggestam

karin.aggestam@svet.lu.se

Annika Bergman Rosamond

annika.bergman_rosamond@svet.lu.se

1 Department of Political Science, Lund University, Lund, Sweden
A key contention in this article is that the digital articulation of feminist foreign policy has projected a self-narrative of a just state, committed to gender equality, representation and rights within and beyond borders.

In contemporary global politics, states are investing in the digital management of their national images and relationships online (Hedling 2020). The use of information and communication technologies (ICTs) in the pursuit of diplomatic goals has become an important practice whereby foreign policy actors can digitally project their policy preferences, normative values and nation brands globally (Bjola and Holmes 2015). Leaders, states, governments and a variety of organisations increasingly use social media to project their influence beyond borders, enabling them to reach and manage domestic and global publics (Duncombe 2019; Wright 2019; Aggestam and Hedling 2020). Digital diplomacy, moreover, has changed the ways in which states manage their nation brands and this has amplified the reach and role of public diplomacy in global politics (Manor 2019). The Internet has developed from a place of technological enthusiasm and democratic potential, to a space in which states strategically project, contain and contest national narratives as well as promoting new global policy initiatives (Bjola and Pamment 2016; Bos and Melissen 2019). 
Together such new digital practices constitute major transformations of diplomacy, in particular in relation to the ways in which they have adjusted and adapted to the emergence and consolidation of new digital global environments. Yet, there are few studies that have applied gender or feminist perspectives to the analysis of digital diplomacy (Jezierska and Towns 2018; Wright 2019; Wright and Guerrina 2020; Jezierska 2021).

In this article, we contribute to the burgeoning literature on digital diplomacy by focussing on feminism and foreign policy change. We draw on three strands of research: digital diplomacy, foreign policy analysis (FPA) and feminist scholarship. This involves studying the ways in which digital diplomacy have developed and adapted to the emergence of feminist foreign policy as a method of achieving transformative gender justice globally. In this way, we hope to advance feminist perspectives on place branding and public diplomacy by focussing on the explicit communication practices of actors dedicated to state feminism (Hernes 1987; Stetson and Mazur 1995; Bergman Rosamond 2020).

Sweden's communication of feminist foreign policy has been conducted through active use of digital diplomacy to project its external priorities and visions (Government Offices of Sweden 2019b). This is consistent with Sweden's tendency to advance its foreign policy objectives through the employment of digital platforms, enabling it to effectively brand and sediment its longstanding internationalist ambitions and goals.

The country has also been at the forefront of digital diplomacy (Pamment 2012; Christensen 2013), with the former Conservative Foreign Minister Carl Bildt being considered a leader in the field (Madestam and Falkman 2017). In the analysis below, we highlight the continuity of Sweden's digital diplomacy and the changes that have emerged from the feminist reorientation of its foreign policy which commenced in 2014.

We advance the concept of feminist digital diplomacy, which we define as a method and normative platform whereby states and other actors employ digital means to highlight their commitment to the transformation of gendered injustices in global relations. Key to this endeavour is the growing tendency among a number of states to conduct pro-gender foreign policy platforms (Aggestam and True 2020). Here we propose that Sweden's introduction of a distinct feminist foreign policy as well as its adoption of new digital diplomatic strategies significantly have altered the trajectory of Sweden's diplomacy. These processes, moreover, provide a platform for the conduct of feminist digital diplomacy.

To illustrate this development, we trace the positioning of feminism in Sweden's outward projection of its foreign policy goals and priorities through digital diplomacy by focussing on the period after 2014. Here it is interesting to note that Sweden's digitally communicated feminist image is a relatively new phenomenon. In this context, Jezierska and Towns (2018), see also Jezierska (2021) observe that "feminism" was not more pronounced in Sweden's nation branding efforts after 2014, when the new direction in external conduct was adopted. Rather, it was omitted from the "Progressive Sweden" brand in favour of less antagonistic values including gender equality.

Our study demonstrates how a range of strategic attempts, often initiated by the Swedish Ministry for Foreign Affairs, sought to project feminist foreign policy through the employment of a "Feminist Power Sweden" narrative starting in year 2015 (Wright and Guerrina 2020). ${ }^{1}$ However, that narrative was carefully told so as not to disrupt the less antagonistic brand of "progressive Sweden" (Jezierska and Towns 2018) - a brand less radical than that of "Feminist Power Sweden". Our study primarily explores the integration of feminist foreign policy into digital diplomacy rather than assessing the extent of Sweden's gender equality activities in social media (cf. Jezierska 2021). In particular, we focus on the efforts by the Swedish Ministry for Foreign Affairs (MFA) to actively communicate the normative underpinnings and preferences of feminist foreign policy across digital settings.

The article is structured as follows. First, we elaborate on the conceptual merits of combining digital diplomacy, feminist scholarship and FPA to study the role of foreign policy change. Second, we outline the methodology employed to trace the development of Sweden's digital diplomacy narrative, before and after its adoption of a distinctively feminist foreign policy. Third, we provide an empirical case analysis of Sweden's foreign policy change and conduct of digital diplomacy during the period 2006-2020. In so doing we explore documents available on the official websites of the Government Offices of Sweden and the Ministry for Foreign Affairs, including sites such as SwedenAbroad and Swedish Foreign Policy Stories. We conclude by reflecting on the constitutive links between the digitalization of Swedish diplomacy and its adoption of feminist foreign policy in 2014. We posit that Sweden's conduct of feminist digital diplomacy has both strengthened its feminist self-narration and offered new opportunities to communicate typically Swedish pro-gender values globally. We also note that Sweden had a competitive edge in global politics and acted on a window of opportunity enabling it to advance feminist digital diplomacy, which in turn sparked global outreach and attention. In particular we emphasise the centrality of

\footnotetext{
1 Wright and Guerrina (2020) advances the concept of 'Feminist Power Europe' to critically explore the feminist and pro-gender ambitions of the EU project.
} 
political leadership in the transformation of Swedish foreign policy and diplomacy.

\section{Digital diplomacy and foreign policy change}

In the last decade, there has been an upsurge in studies of digital diplomacy to explain the intersection between foreign policy and technology (Archetti 2012; Hayden 2012; Manor and Segev 2015; Bjola and Manor 2018; Duncombe 2019). Such scholarship defines digital diplomacy in broad terms, including a wide range of diplomatic initiatives and practices as well as information technologies (ICTs) (Bjola and Holmes 2015). Many studies have sought to understand how the engagement practices of "public diplomacy" and efforts of "nation branding" have materialised in social media (Manor 2019). It should be noted here that social media has often been understood and defined as channels for interstate dialogue (Duncombe 2017) as well as non-state diplomacy (Bos and Melissen 2019).

While many insightful analyses of these new forms of diplomatic practice have been offered, the role of normative foreign policy change has been less studied. In this article we explore the significance of women's political leadership, their inclusion in bureaucratic politics as well as the prevalence of pro-gender norms in domestic society for the adoption of Sweden's feminist foreign policy and its distinct conduct of feminist digital diplomacy.

The rise of feminist foreign policy has entailed change through both the employment of a pronounced feminist agenda, governing domestic and global politics, as well as a reorientation of diplomatic practice. While Sweden has a long tradition of promoting gender justice, equality and representation at home and abroad, and coupling its state feminist tradition with "gender cosmopolitanism" in foreign policy, the extent to which it has done so in recent years is unprecedented (Bergman Rosamond 2020). Moreover, gender cosmopolitanism is closely connected to the country's support for UN Security Resolution 1325 on Women, Peace and Security (WPS), which provided impetus for the adoption of Sweden's feminist foreign policy in 2014 (Aggestam and Rosamond 2021). In short, though FFP is located within Sweden's longstanding commitment to gender equality and justice globally, the use of digital technologies to communicate its contents and ambitions is innovative and reflects a significant change in Sweden's overall foreign policy narrative and practice.

A common assumption within foreign policy analysis (FPA) is that change results from an interplay of domestic and international factors and developments (Holsti 2015; Hudson and Day 2019). For example, at the domestic level there is an assumption that leadership, bureaucratic agency and domestic politics are drivers of policy change
(Hermann 1990; Holsti 2015). Leaders may drive change through political conviction leading them to communicate their new visions of foreign policy (Hermann and Hagan 1998) to national and global audiences. Such leaders may be individuals or groups that play an important part in visualising foreign policy shifts as well as innovative approaches to global politics and foreign policy practice.

Foreign policy change may also be driven by bureaucratic agency whereby groups within governments or governmental organisations initiate or actively pursue policy change. Key here is the particular organisational culture within ministries for foreign affairs, and whether that culture is conducive to foreign policy change and innovative political leadership (Drezner 2000). The distinctive features of a particular state's political culture, domestic politics, norms and national interests also affect the extent to which thoroughgoing foreign policy change is possible (Bergman Rosamond 2020). Changing the direction of national foreign policymaking might also be a response to public opinion or calls for change among elite groups in society. For instance, a new government may change the direction of foreign policy as a result of increase in public support for a particular issue or development such as environmental justice. Though FPA models vary in how much emphasis they place on the aforementioned analytical tools, all three levels of analysis ${ }^{2}$ are key to the exploration of foreign policy change.

\section{Methodology}

Sweden could be considered a forerunner of digital diplomacy, with new diplomatic practices emerging from the digitalisation of its foreign policy, associated with the centre-right coalition governments that were in power between 2006 and 2014. Digital diplomacy, as discourse and practice, faced a major shift when an explicitly feminist foreign policy was adopted by the Swedish red-green coalition government in 2014, giving rise to changing endogenous and exogenous conditions for Sweden's external conduct. As we show below, Sweden's digital self-narrative has adopted prominent feminist tropes, portraying the nation as gender aware, committed to women's and girls' rights and using its foreign policy to promote that self-image.

In analysing how feminist foreign policy became embedded in Sweden's digital diplomacy we draw on narrative

\footnotetext{
${ }^{2}$ Aggestam and True (2021) advances a new analytical concept of "gendered multilevel games" to analyse how political leaders harness gender dynamics to further their power, status and authority to act in foreign policy. This new concept highlights the problem of agency and structure in foreign policy, both of which are generated from the intersections between the domestic, international and transnational levels, and their reach within and across states.
} 
methodology (Somers 1994). Specifically, we trace change in Sweden's self-branding narratives (Strand and Kehl 2019), and, to what extent they articulated an image of Sweden as a "legitimate and capable" actor (Khamis et al. 2017, p. 34), enabling it to adopt a feminist foreign policy before other nations. Relevant here is Miskimmon et al.'s (2013) conception of identity narratives and the assumption that identities of international actors "are in a constant process of negotiation and contestation" (Miskimmon et al. 2013, p. 7). Thus, Sweden's self-branding narratives are both a reflection of the continuity of its state identity and process of re-negotiation following political change (Browning 2015).

To illustrate such continuity and foreign policy change we analyse Sweden's digital diplomacy during the period 2006 to 2020 . This involves identifying both patterns of consistency as well as changes in Sweden's employment of digital diplomacy during that period. This enables us to make assessments of the distinct policy changes that were introduced as a consequence of the adoption of Sweden's feminist foreign policy in 2014, many of which were communicated through digital diplomatic channels. The analysis below rests on a variety of data including the annual foreign policy declarations of the Swedish government, public strategy documents and press releases, outlining Sweden's foreign policy and the role of digital diplomacy therein. Moreover, we draw on data published on the official websites of the Swedish Ministry for Foreign Affairs, including Government Offices of Sweden, SwedenAbroad and Swedish Foreign Policy Stories. In addition, we have analysed the official YouTube, Twitter and Facebook accounts of government ministers and the Swedish Ministry for Foreign Affairs.

It is important to note that the empirical material that we use either explicitly refers to "digital diplomacy" or is communicated as "digital diplomacy" by the MFA (for instance through the adjoining hashtag \#digitaldiplomacy). Thus, it does not represent a comprehensive account of Sweden's conduct of digital diplomacy. Rather we analyse a sample of such efforts that have been strategically projected in digital settings. Nonetheless, those samples reflect the distinctive features of Swedish digital diplomacy and by studying them we are able to make comparative observations throughout the period of investigation. In particular, we identify the ways in which hashtags and themes are employed in Swedish digital diplomacy. We trace the introduction and use of hashtag \#feministforeignpolicy and other feminist hashtags employed to visualise and promote campaigns and initiatives, such as \#girlstakeover, \#shedecides, \#morewomenmorepeace, \#heforshe, \#feministfriday and \#equalitymakessense. However, our empirical analysis does not include a systematic study of the efforts by individual members of the Swedish government to project feminist values beyond borders, or safeguarding the image of Sweden abroad (e.g. by embassies). Rather the study offers a case illustration of feminist digital diplomacy in progress by providing an account of the development of Sweden's digital diplomacy over a central time period.

It should be noted that our empirical analysis focuses on the development of Sweden's digital diplomacy both before and after the launch of Sweden's feminist foreign policy in 2014. Drawing upon FPA, our position here is that foreign policy change emerges from the influence of leadership, bureaucratic agency and domestic politics-independently or in combination.

Our analysis, moreover, follows a chronological order in which we consider the continuity of Sweden's digital diplomacy, in accordance with domestic drivers for change. Our analysis shows that Sweden's adoption of digital diplomacy during the period 2006-2014 was grounded in the country's broader enthusiasm for information technology at the time, with Carl Bildt, a top diplomat and Sweden's former Conservative Prime Minister and Foreign Minister, envisaging it as a key dimension to Sweden's national foreign policy agenda. When the new red-green government launched the feminist foreign policy agenda in 2014, a similar pattern of digital promotion gradually produced new digital actions, including online campaigns for gender justice globally in line with the new government's feminist foreign policy ambitions. Thus, the adoption of feminist digital diplomacy is an incremental process that has gained ground over time.

\section{From digital promotion to feminist action: political leadership, bureaucratic agency and domestic politics}

In this part of the article, we demonstrate the significance of political leadership, bureaucratic agency as well as the role of domestic politics in shaping government policy and foreign policy change. However, before doing so we briefly reflect on Sweden's modernist self-image. Sweden has for long projected itself as a modernist nation, devoted to progressive values and internationalist transformations of international society (Bergman 2007)—digital technology offered opportunities to strengthen this self-narrative. As alluded to above, Sweden's early anticipation of digital diplomacy was hardly surprising, considering its active promotion of the use of ICT in international development policy since the 1990s. To this end, Sweden invested heavily in technological advancements and projected an image of being a global leader in the realm of communication technologies (Pamment 2012). For example, as early as in 1995, the Swedish government created the National Board for the Promotion of Sweden to strategically coordinate the image of Sweden abroad, mobilising its international image as an innovative and creative state. The idea was to project Sweden's image as a free and open society to global 
audiences, with four profile areas being emphasised as part of this quest; innovation, society, creativity and sustainability (National Board for the Promotion of Sweden 2017). Pioneering digital diplomacy was therefore compatible with Sweden's "progressive" state image and self-narrative, couched within modernity and forward thinking, coupled with its early interest in the digital economy.

Sweden's development of digital diplomacy was specifically driven by the political leadership of former Foreign Minister and Prime Minister Carl Bildt (Pelling 2016, p. 170; Manor 2019, p. 223). Bildt had since the 1980s been an advocate of ICT and took a number of digitalising initiatives during his time in office (1991-1994) — he used his political platform in a proactive way to promote the digitalisation of foreign policy and diplomacy. In 1994, while serving as Sweden's prime minister, Bildt was allegedly the first head of state to send an e-mail to another head of state (to US president Bill Clinton) (Christensen 2011).

In addition to providing new opportunities to promote the state image of Sweden as a technologically friendly nation, digital tools and strategies were widely embraced to improve the government's global outreach (Bengtsson 2011). For example, Bildt made digital and internet freedom an important part of his political platform. This projected a state image of a country committed to transparency and accountability domestically and globally. Hardly surprising then, a decade later, while serving as Sweden's Minister of Foreign Affairs (2006-2012), Carl Bildt was among the first leaders to write a blog, use Twitter and launch a YouTube channel to communicate his diplomatic activities to global publics (Madestam and Falkman 2017). Hence, Bildt set the scene for the future digitalisation of Swedish diplomacy and foreign policy, although without an enthusiasm for Sweden's longstanding commitment to pro-gender norms.

\section{The role of foreign policy bureaucracy in driving change-state image, outreach and networking}

As noted above, Sweden's digital diplomacy evolved against the backdrop of the wider promotion of its innovative and changing state image and self-narrative, as well as its proneness to engage in outreach and policy networking. This state image has been actively promoted by the Swedish Ministry for Foreign Affairs, using its bureaucratic agency and adopting a range of strategies and campaigns to communicate notions of the modern and innovative self. For instance, in 2007 Sweden was the first state in the world to launch and establish a "virtual embassy" in the online virtual world "Second Life" (a freely accessible software that allows people to immerse in a virtual world).

The goal of the virtual Swedish embassy was to cultivate direct engagement with Second Life users and serve as a pilot study through which Swedish officials could learn more about how to communicate their country's foreign policy visions in digital settings (Pamment 2012). The virtual embassy led to substantial international media coverage and Sweden was able to connect its nation brand to the project of a digital future (Bengtsson 2011), narrating the nation as an innovative and forward-looking actor. In 2010, the Swedish MFA launched its own blog and, in 2011, the Swedish government, via the Swedish Institute and "VisitSweden," launched the digital campaign "Curators of Sweden" on its @ Sweden Twitter account (Curators of Sweden n.d.). Inspired by the use of social media (and its democratic potential) by activists engaged in the uprisings in the Middle East, the @ Sweden account allocated space for ordinary Swedish citizens to present their versions and images of Sweden to global publics (Christensen 2013).

After the first years of experimenting with digitalisation and digital communication channels designed for promotion and outreach purposes, Sweden's digital diplomacy moved towards extensive collaboration and networking with stakeholders. Digital diplomacy then provided new ways in which Sweden could engage with such actors, and, in so doing, project an image of an innovative state engaged in dialogue and openness (Pelling 2016). In 2012, the MFA, acted on its bureaucratic agency by launching the Stockholm Internet Forum, which has since then become an annual event. It aimed at deepening the debate, among IT enthusiasts, business representatives, human rights and internet activists, and policymakers on how freedom and openness on the Internet can stimulate global economic development. The initiative and the work behind it also aimed to promote a UN resolution of freedom of expression online, which was then adopted by the United Nations (UN) Human Rights Council in June 2012 (Bildt 2012). It should be noted here that at the time no distinct effort was made to use digital tools to promote Sweden's self-narrative as a feminist state. Instead, Sweden was projected as a country "at the absolute cutting edge in digital diplomacy efforts" based on the recognition that "public diplomacy is becoming increasingly important" (Government Offices of Sweden 2013b).

Furthermore, the MFA vowed that all Swedish embassies were to establish presence on Facebook and Twitter, a goal they proudly announced that they had reached on a blog two months later (Government Offices of Sweden 2013a). In 2013, the Swedish embassy in London, in collaboration with the Dutch embassy, hosted the first (of many) "diplohacks", to develop stronger networks between diplomats, civil society representatives and developers (Clase 2013). The diplohack centred around questions of freedom of expression online and the role of data and technology to improve sustainability in the food supply chain. Similarly, in 2014, Sweden hosted a 24-h event titled the "Stockholm Initiative for Digital Diplomacy" (SIDD), which among other 
things, gathered diplomats and academics to discuss ways forward in the digitalisation of diplomacy. This event was again aimed to produce new collaborations and networks to inform policy-making and further digital communication in diplomacy.

Our account above shows that the Swedish MFA used its bureaucratic agency to communicate an image of Sweden as a cutting edge and digitally sassy nation. Indeed, Sweden's foreign policy narrative from the 1990s onwards was defined by an active use of technological innovation and digital change- - key aspects of its diplomatic communication. Sweden has since that period employed "diplomacy of technology", rather than using digital tools and platforms to achieve specific foreign policy goals and proactively manage Sweden's reputation online. Rather, the overarching ambition of Swedish digital diplomacy has been to project the nation's self-image and modernist narrative onto the international stage (Pamment 2012). Thus, the use of digital diplomacy has offered opportunities to attract foreign policy attention, ensuring that audiences are being made aware of the country's digital sophistication (Govers 2015).

During the period between 2006 and 2012 that strategy specifically entailed putting across the message that Sweden was digitally ahead of other nations. Jon Pelling, a former head of communication at the Swedish embassy in London, has noted that "doing something in new ways can itself become the message, initiating change and enabling further relationship-building" (Pelling 2016, p. 170).

In many ways, Sweden's approach to digital diplomacy was during this period apolitical and, therefore, void of feminism. However, Sweden was not alone in this regard-a good number of governments at the time launched generalist digital and technological diplomatic initiatives, without necessarily envisaging these as routes to profound normative change. Rather they viewed such moves as a way of improving communications with domestic and global publics (Manor 2019). Yet, the Swedish MFA's active exploration and implementation of new digital technologies laid the foundation for the conduct of feminist digital diplomacy by the red-green coalition government.

Next, we turn to the feminist rebranding of Swedish foreign policy and self-narrative by exploring the linkages between feminist foreign policy and digital diplomacy. We argue that domestic support for the new Swedish government in 2014 opened up for the launch of an innovative feminist platform for foreign policy, which in turn provided a window of opportunity for the Swedish MFA to broaden, and deepen its repertoire of digital diplomacy, adding a new chapter to its strategic self-narrative.

\section{The branding of Sweden's feminist foreign policy and self-narrative}

As noted above, the new red-green coalition government that came into office in 2014 immediately declared a major change in Sweden's foreign policy narrative, by adopting a distinct feminist agenda. The ambition was no less than becoming the "strongest voice for gender equality and full employment of human rights for all women and girls" (Government Offices of Sweden 2015b). This shift could be viewed as an exercise in political leadership by the new government, but also as an expression of its support for the global gender norms embodied in United Nations Security Council Resolution 1325 on Women, Peace and Security. Indeed, Swedish feminist foreign policy is firmly based on its support for the advancement of UN Security Council resolution 1325 and the WPS agenda (Aggestam and Bergman Rosamond 2021).

Central to this major foreign policy shift is also the feminist leadership and personal engagement of former Foreign Minister Margot Wallström (Aggestam and Bergman Rosamond 2019; Aggestam and True 2021), an internationally recognised diplomat who was the first person to hold the position as Special Representative of the Secretary General on Sexual Violence in Conflict. As a newly appointed foreign minister Margot Wallström tweeted that "without representation, rights and resources for women we will never have peace and security. Women's rights are human rights." (Wallström n.d.). Indeed, the adoption of feminist foreign policy was digitally projected by various ministers and the government itself as an exercise in innovation and political leadership (Bergman Rosamond 2020).

As noted above, while feminist foreign policy is innovative and new, located within an ethical commitment to the eradication of gendered injustices globally, it builds on longstanding domestic support for pro-gender norms and cosmopolitan-informed foreign policy orientations (Bergman Rosamond 2020). This normative commitment has been expressed in support for the rights, bodily integrity and wellbeing of women and girls, however, with less attention being paid to other intersectional categories (Aggestam and Bergman Rosamond 2019, 2021). In many ways feminist foreign policy provided an opportunity to externalise Sweden's state feminist tradition, which is expressed in statist support for gender equality, social policy and women's representation in political parties and institutions (Bergman Rosamond 2020); see also (Hernes 1987; Mazur and Stetson 1995). In line with that feminist tradition the Swedish government declared in 2014 that it is a "feminist government," which entails "building a society in which women and men, girls and boys can live their lives to their full potential and in which gender equality is a matter of human rights, of democracy and of justice" (Government Offices of Sweden 2016). Thus, the 
domestic political context was favourably disposed to the introduction of feminist foreign policy in 2014, though it has been contested by certain political parties including the far right Swedish Democrats (Bergman Rosamond 2020).

Nonetheless, from the outset digital diplomacy, communication and dialogue were key to the conduct and projection of feminist foreign policy. That shift built on Sweden's firmly established self-narrative as an innovative and modern nation committed to normative change and technological advancement. One of the first steps in the implementation of Sweden's digital self-identity and narrative was to ensure that its foreign policy communication was streamlined within distinct feminist principles and terms. Indeed, the use of feminist terminology in digital communication was considered an effective way of reaching "normative influence" in global affairs (Government Offices of Sweden 2019b). Paradoxically, the new self-declared feminist government initially dropped Sweden's previous ambitious agenda of promoting and expanding digital diplomacy. For example, digital diplomacy was not a prominent discursive theme in the Swedish annual foreign policy declarations between 2015 and 2020.

In 2014, new steps nonetheless were taken which recognised that Sweden's newly adopted feminist foreign policy platform required innovative forms of digital diplomacy, including strategic leadership, priorities and policy adaption. As we shall show below the Swedish MFA played a significant role in this process by launching a range of digital campaigns that evoked attention globally. Gradually, Sweden's digital diplomacy became more aligned with its overall feminist foreign policy objectives, and, less focus was placed on Sweden's self-image as a progressive and tech savvy state. Again, we wish to highlight the feminist leadership of Margot Wallström here, which not only inspired the adoption of feminist foreign policy itself, but also the active use of digital means in communicating the normative goals of that major foreign policy change. She often took to Twitter and Facebook to communicate the transformative ambitions and direction of Sweden's feminist foreign policy (Wallström n.d.) Indeed, since 2014, \#feministforeignpolicy has been one of the top three most frequently used hashtags by the Swedish MFA. Furthermore, since the launch of the public diplomacy website Swedish Foreign Policy Stories (www. swemfa.se) in 2018, feminist foreign policy has been one of the main themes in the MFA's concerted efforts to engage an international audience with Swedish foreign policy (Swedish Ministry for Foreign Affairs 2018). The website publishes stories about feminist foreign policy in practice as well as the promotion of gender equality in Swedish foreign policy.
The efforts to broaden and deepen Sweden's feminist digital diplomacy have also been reflected in a number of social media campaigns. These have centred around the three pillars of Sweden's feminist foreign policy (rights, representation and resources) and its six prioritised areas. ${ }^{3}$ For instance, Sweden proactively supported \#GirlsTakeover, initiated by the organisation Plan International - an initiative aiming to enable girls throughout the world to occupy positions of power. The country also took active part in the International Day of the Girl Child on 11 October (Government Offices of Sweden 2019a). By promoting the hashtag and its message in various communication channels, Swedish foreign missions in 21 different countries arranged various activities, giving girls the opportunity to act as diplomats for a day (Embassy of Sweden Jakarta Indonesia 2019). Another initiative, launched by the MFA, is the \#midwives4all initiative, with the explicit ambition to highlight the central role of midwives to ensure the reproductive health of women and girls, and, using digital diplomacy to mobilise support for that particular professional category (Handbook Sweden's feminist foreign policy 2019). The campaign was in fact planned by the MFA before the election victory of the redgreen coalition in 2014, but then ended up becoming a key theme in the projection of feminist foreign policy in social media (Wihlborg and Norstedt 2017). These initiatives are instructive examples of the MFA exercising bureaucratic agency in digitally communicating the normative values of feminist foreign policy.

Indeed, the area of Sexual and Reproductive Health Rights (SRHR) constitutes one of the six prioritised goals underpinning feminist foreign policy, and is a key theme in Sweden's feminist digital diplomacy. Matters related to SRHR have attracted more attention in recent years, particularly against the backdrop of the increasing contestation of pro-gender norms in global politics (Agius et al. 2020) and the global backlash against women's and girls' human rights (Aggestam and True 2021).

To counter and resist this global trend, Sweden was among the initiators of the hashtag \#Shedecides campaign in 2017. The campaign was a way for the Swedish government and its ministers to manifest concrete feminist foreign policy actions, adding force to its quest for global normative leadership and the formation of broad international coalitions of "women friendly" states and NGOs. Moreover, it helped to sediment the feminist shift in Sweden's foreign policy narrative and diplomatic practice.

\footnotetext{
3 (1) Full enjoyment of human rights, (2) Freedom of physical, psychological and sexual violence, (3) Participation in preventing, resolving conflicts, and post-conflict peacebuilding (4) Political participation in all areas of society, (5) Economic rights and empowerment, and (6) Sexual and reproductive health and rights (Government Offices of Sweden 2019b)
} 
The campaign aimed to raise funds to compensate for the "global gag rule" re-instated and expanded by the President of the United States, Donald Trump. The global gag rule, with its extended decree, aimed at reducing international development assistance that specifically financed human rights advocacy and work in global politics. Moreover, it prohibited American development assistance finance to international NGOs which support women's sexual reproductive rights. In addition to the global gag rule, states such as Russia, Bahrain, Guatemala, Philippines Saudi Arabia, Indonesia and Nigeria, have mobilised global campaigns and alliances to roll back on gender equality, SRHR and the Lesbian Bisexual Gay and Transgender (LBGT) movements, viewing them as anti-family and pro-abortion policies (Aggestam and True 2021).

Isabella Lövin, the former Swedish Minister for International Development Cooperation and the Environment, used her political position and female leadership to oppose the global gag rule. Among other things, she posted an image of herself signing a climate bill on Facebook, which alluded to Trump's signing of the global gag rule. Lövin's official Facebook site went viral in social media and was represented by major international news outlets (BBC News 2017). When Lövin was asked to comment, she stated: "we are a feminist government which this photo shows: Ultimately it is up to the observer to interpret the photo." (Roden 2017). The image of Lövin, surrounded by female colleagues, signing a bill attained a life of its own in social media and it has been used by activists and organisations to promote feminism domestically and globally.

Other social media campaigns have been used to advocate and raise awareness of Sweden's feminist foreign policy agenda. As noted above the MFA has actively sought to communicate new initiatives using feminist hashtags such as \#morewomenmorepeace, \#heforshe, \#feministfriday and \#equalitymakessense on social media (Government Offices of Sweden 2019c). To this end, the MFA communications team has developed communication packages that are further appropriated and disseminated by Swedish embassies (Government Offices of Sweden 2019b, pp. 39-41). Several of these hashtags have become important international sites for norm contestation as well as platforms for debating the very idea of feminism (illustrated by the rise of the \#metoo movement) (Brown et al. 2017; Griffin 2019). Rather than declaring ownership of these hashtags, the MFA has adopted a collaborative approach to digital feminism by encouraging others to join "the conversation", tapping into Sweden's selfidentity as a collaborative and dialogical international actor (Bergman Rosamond 2020). Such promotion of digital feminism also characterised the communication efforts of Sweden's tenure in the UN Security Council 2017-2018, with the latter offering an opportunity to strengthen Sweden's feminist leadership and self-narrative. Moreover, Sweden habitually organise online Twitter Q\&A sessions, hosted by a range of Swedish embassies (Government Offices of Sweden 2019b), providing opportunities for people to engage with Swedish diplomats online. During these sessions, Swedish ambassadors and diplomats respond to live questions in Twitter feeds, which often concern topics related to feminist foreign policy. The use of individual ambassadors for such communication purposes demonstrates the significance of bureaucratic agency in launching new foreign policy initiatives.

The Swedish government has also sought new ways of continuing the tradition of developing digital diplomacy by experimenting with new digital formats. By way of illustration, in 2017 former Foreign Minister Margot Wallström hosted the world's first public digital meeting of female foreign ministers which was broadcast live on Facebook, Twitter and YouTube. Participants included the foreign ministers of Colombia, Kenya, Panama and Liechtenstein and the purpose was to publicly discuss issues relating to the WPS agenda (Government Offices of Sweden 2017). By acting on her feminist leadership and by promoting transparency through a public meeting accessible online, the foreign minister herself took active part in the communication of Sweden's feminist digital diplomacy. The event was also a way of highlighting the potential of feminist digital diplomacy, in particular by offering opportunities for female foreign ministers to come together, exercise female leadership and deliberate on feminist issues. The event was communicated by the MFA using hashtag \#digitaldiplomacy, which signalled that it was conceptualised as a strategic effort to profile Sweden's new feminist digital diplomacy, and adding strength to the country's feminist brand and self-narrative.

Another example of Sweden's advancement of feminist digital diplomacy was the initiative by the Swedish MFA and more than 50 of its embassies to host "edit-a-thons" on International Women's Day in 2018. The aim was to increase the number of articles about women and their role in various aspects of society, politics and history on Wikipedia. Thus, it was a conscious effort to address the lack of women's stories on Wikipedia - there are four times more articles about men than women in that forum (Government Offices of Sweden 2018a). The success of the event triggered a larger initiative, under the banner "\#WikiGap". Within the framework of the initiative, the MFA has collaborated with Wikimedia by hosting global "edit-a-thons" (Government Offices of Sweden 2018b). \#Wikigap has been upheld by the Swedish government as a key example of the country's feminist foreign policy success, by increasing the representation of women and their life stories on Wikipedia (Government Offices of Sweden 2018a, b). In 2020, \#WikiGap had produced more than 35,000 Wikipedia articles on prominent women in more than 30 different languages, and, thus, we would argue, is a key achievement of Sweden's feminist digital diplomacy. 


\section{Criticism and contestation}

While Sweden's activist feminist approach to digital diplomacy has received praise and global attention it also has triggered criticism and contestation (Standish 2016; Rosén Sundström and Elgström 2020). Specifically, criticism has been directed towards the initial uncertainty of how to implement feminist foreign policy (Egnell 2016). The feminist framing of foreign policy has also been discussed in relation to the polarisation and political antagonism that it could give rise to, which explains why it was for long absent from Sweden's more general nation branding strategy (Jezierska and Towns 2018; Rosén Sundström and Elgström 2020). This sensitivity is also notable in recent efforts to use digital diplomacy for the purpose of containing the rising threats posed by digital disinformation (Bjola and Pamment 2018, 2016). By way of illustration, in her first annual foreign policy declaration, Margot Wallström declared that "digital propaganda wars" are the "new security threats" that "must be fought" (Government Offices of Sweden 2015a). Thus, Sweden's feminist foreign policy has coincided with a more competitive information environment that has positioned the country in the midst of normative confrontation in international politics. Nevertheless, the digital projection of Sweden's feminist foreign policy has helped to sustain the country's self-narrative as a state committed to the rights, resources and representation of women and girls globally. While the adoption of FFP is a significant foreign policy change, facilitated by political leadership and commitment as well as the MFA's active employment of digital campaigns and strategies, it is also a continuation of Sweden's domestic state feminist tradition and support for gender equality.

\section{Conclusion: towards feminist digital diplomacy}

In this article, we have explored the ways in which Sweden has digitally projected its state image since the mid-2000s. More specifically, we have investigated the country's adoption of a distinctively feminist digital diplomacy, emerging from its self-image as an innovative, progressive and gender aware state. What is more, we have demonstrated that this turn in Swedish diplomacy can be intimately linked to the digital communication of FFP, in particular, Sweden's commitment to feminist transformations of global injustices. Sweden's active conduct of feminist digital diplomacy has both strengthened its feminist self-narration and offered new opportunities to communicate typically Swedish pro-gender values to large audiences. Our analysis shows that Sweden's foreign policy leadership and the bureaucratic agency of its MFA as well as a favourable domestic political context have been central to the incremental development of Sweden's feminist digital diplomacy. By way of conclusion, we argue that Sweden has had a competitive edge on two distinct fronts, both of which have provided a window of opportunity to advance novel forms of feminist digital diplomacy and to successfully reach global audiences. First, Sweden was from the outset responsive to the need of investing in the digital diplomatic management of its state image online and to use social media as a way of enhancing its domestic and global outreach. As such, the promotion and usage of new digital tools and practices reflect how Swedish diplomacy swiftly adjusted and adapted to the new digital arenas of global politics. Second, Sweden was the first country in the world to launch a feminist foreign policy, ${ }^{4}$ a shift that was actively supported by its foreign policy leadership and the bureaucratic agency of its foreign services. Such a novel foreign policy change trigged by itself global attention and outreach. This article concludes by noting that these two factors have served as favouring conditions and assisted the advancement of a feminist digital diplomacy. As our analysis has shown, the adoption of a feminist platform for foreign policy-making and embracing new diplomatic strategies have altered the trajectory of Sweden's digital diplomacy. As part of the effort to launch and brand the country's new feminist foreign policy, the Swedish MFA proactively created a broad range of communications, material, digital platforms and campaigns. For instance, in the quest to reach a variety of targeted audiences, Swedish embassies around the world coordinated their digital diplomatic strategies by using hashtags, Twitter sessions and by responding to live questions and answers in Twitter feeds. Without such bureaucratic agency and political leadership, it is doubtful whether the transformation of Swedish diplomacy and foreign policy would have taken the same shape. Indeed, the foreign policy leadership of Carl Bildt and Margot Wallström was decisive and opened for the active use of new digital diplomatic means and foreign policy change. Both ministers' enthusiasm for digital technology was central to the successful branding of Sweden's state image, self-narrative and foreign policy conduct. The Swedish case then demonstrates that changes in states' digital diplomacy can be driven by multiple and at times correlating factors. This implies that the adoption of a feminist framing of foreign policy may not automatically translate into feminist digital diplomacy. At the same time, feminist digital diplomacy is evolving in an antagonistic world where the WPS agenda and the core pillars of Sweden's feminist foreign policy (rights, representation and resources) are increasingly contested and resisted. Feminist digital diplomacy is, therefore, likely to grow in

\footnotetext{
${ }^{4}$ Since then, France, Canada and most recently Mexico have adopted a feminist framing of their foreign policies.
} 
importance as a method for states to pledge commitment to the transformation of gendered injustices in global relations.

Acknowledgements The authors gratefully acknowledge funding from the Marianne and Marcus Wallenberg Foundation (project number 2018.0090).

Open Access This article is licensed under a Creative Commons Attribution 4.0 International License, which permits use, sharing, adaptation, distribution and reproduction in any medium or format, as long as you give appropriate credit to the original author(s) and the source, provide a link to the Creative Commons licence, and indicate if changes were made. The images or other third party material in this article are included in the article's Creative Commons licence, unless indicated otherwise in a credit line to the material. If material is not included in the article's Creative Commons licence and your intended use is not permitted by statutory regulation or exceeds the permitted use, you will need to obtain permission directly from the copyright holder. To view a copy of this licence, visit http://creativecommons.org/licenses/by/4.0/.

\section{References}

Aggestam, Karin, and Annika Bergman-Rosamond. 2016. Swedish feminist foreign policy in the making: Ethics, politics, and gender. Ethics \& International Affairs 30 (3): 323-334.

Aggestam, Karin, and Annika Bergman-Rosamond. 2019. Feminist Foreign Policy 3.0: Advancing ethics and gender equality in global politics. SAIS Review of International Affairs 39 (1): $37-48$.

Aggestam, Karin, and Annika Bergman-Rosamond. 2021. Gender and peaceful change. In The Oxford handbook of peaceful change in international relations, ed. T.V. Paul, Deborah Welch Larson, Harold A.. Trinkunas, Anders Wivel, and Ralf Emmers. Oxford: Oxford University Press.

Aggestam, Karin, and Jacqui True. 2020. Gendering foreign policy: A comparative framework for analysis. Foreign Policy Analysis 16 (2): 143-162.

Aggestam, Karin, and Jacqui True. 2021. Political leadership and gendered multilevel games in foreign policy. International Affairs 97 (2): 385-404.

Aggestam, Lisbeth, and Elsa Hedling. 2020. Leaderisation in foreign policy: Performing the role of EU High Representative. European Security 29 (3): 301-319.

Agius, Christine, Annika Bergman-Rosamond, and Catarina Kinnvall. 2020. Populism, ontological insecurity and gendered nationalism: Masculinity, climate denial and Covid-19. Politics, Religion \& Ideology 21 (4): 432-450.

Archetti, Cristina. 2012. The impact of new media on diplomatic practice: An evolutionary model of change. The Hague Journal of Diplomacy 7 (2): 181-206.

BBC News. 2017. Is Sweden's deputy PM trolling Donald Trump in a Facebook photo?. https://www.bbc.com/news/world-europe38853399. Accessed $03 \mathrm{Feb}$

Bengtsson, Stina. 2011. Virtual nation branding: The Swedish embassy in second life. Journal of Virtual Worlds Research. https://doi.org/10.4101/jvwr.v4i2.2111.

Bergman-Rosamond, Annika. 2007. Co-constitution of domestic and international welfare obligations: The case of Sweden's social democratically inspired internationalism. Cooperation and Conflict 42 (1): 73-99.

Bergman-Rosamond, Annika. 2020. Swedish feminist foreign policy and "Gender Cosmopolitanism." Foreign Policy Analysis 16 (2): 217-235. https://doi.org/10.1093/fpa/orz025.
Bildt, Carl. 2012. Speech by the Swedish Foreign Minister at the Stockholm Internet Forum. Stockholm.

Bjola, Corneliu, and Marcus Holmes. 2015. Digital diplomacy: Theory and practice. London: Routledge.

Bjola, Corneliu, and Ilan Manor. 2018. Revisiting Putnam's twolevel game theory in the digital age: Domestic digital diplomacy and the Iran nuclear deal. Cambridge Review of International Affairs 31 (1): 3-32.

Bjola, Corneliu, and James Pamment. 2016. Digital containment: Revisiting containment strategy in the digital age. Global Affairs 2 (2): 131-142.

Bjola, Corneliu, and James Pamment. 2018. Countering online propaganda and extremism: The dark side of digital diplomacy. London: Routledge.

Bos, Michèle, and Jan Melissen. 2019. Rebel diplomacy and digital communication: Public diplomacy in the Sahel. International Affairs 95 (6): 1331-1348.

Brown, Melissa, Ray Rashawn, Ed. Summers, and Neil Fraistat. 2017. \#SayHerName: A case study of intersectional social media activism. Ethnic and Racial Studies 40 (11): 1831-1846. https://doi.org/10.1080/01419870.2017.1334934.

Browning, Christopher S. 2015. Nation branding, national self-esteem, and the constitution of subjectivity in late modernity. Foreign Policy Analysis 11 (2): 195-214.

Christensen, Christian. 2011. Discourses of technology and liberation: State aid to net activists in an era of "Twitter Revolutions." The Communication Review 14 (3): 233-253.

Christensen, Christian. 2013. @ Sweden: Curating a nation on Twitter. Popular Communication 11 (1): 30-46.

Clase, Nicola. 2013. "\#DiploHack-A platform for new ideas." Swedish Foreign Policy Stories, 29th of September.

Curators of Sweden. n.d. edited by @ Sweden: Twitter.

Drezner, Daniel W. 2000. Ideas, bureaucratic politics, and the crafting of foreign policy. American Journal of Political Science 44 (4): 733-749.

Duncombe, Constance. 2017. Twitter and transformative diplomacy: Social media and Iran-US relations. International Affairs 93 (3): 545-562.

Duncombe, Constance. 2019. Digital diplomacy: Emotion and identity in the public realm. The Hague Journal of Diplomacy 14 (1-2): 102-116.

Egnell, Robert. 2016. Feministisk utrikespolitik i teori och praktik. Statsvetenskaplig Tidskrift 118 (4): 563-587.

Embassy of Sweden Jakarta Indonesia. 2019. Sweden Jakarta took part in \#GirlsTakeover.

Government Offices of Sweden. 2013a. All embassies on Twitter and Facebook. Swedish Foreign Policy Stories, 19th of February.

Government Offices of Sweden. 2013b. Foreign Policy Declaration.

Government Offices of Sweden. 2015a. Foreign Policy Declaration.

Government Offices of Sweden. 2015b. Swedish Foreign Service action plan for feminist foreign policy 2015-2018, including indicative measures for 2018

Government Offices of Sweden. 2016. Foreign Policy Delaration.

Government Offices of Sweden. 2017. World's first public digital meeting of foreign ministers held today. https://www.government.se/ articles/2017/03/worlds-first-public-digital-meeting-of-foreignministers-held-today/

Government Offices of Sweden. 2018a. "WikiGap - let's close the internet gender gap." Swedish Foreign Policy Stories

Government Offices of Sweden. 2018b Sweden to increase gender equality on the internet through \#WikiGap https://www.gover nment.se/press-releases/2018/02/sweden-to-increase-gender-equal ity-on-the-internet-through-wikigap/

Government Offices of Sweden. 2019a. "\#GirlsTakeover-A global initiative to ensure girls' rights and make them visible as actors." Swedish Foreign Policy Stories, 27th September. 
Government Offices of Sweden. 2019b. Handbook Sweden's feminist foreign policy. edited by Ministry of Foreign Affairs.

Government Offices of Sweden. 2019c. Sweden's feminist foreign policy Examples from three years of implementation.

Govers, Robert. 2015. Rethinking virtual and online place branding. In Rethinking place branding, ed. Mihalis Kavaratzis, Gary Warnaby, and J. Gregory. Ashworth, 73-83. Cham: Springer.

Griffin, Penny. 2019. \#MeToo, white feminism and taking everyday politics seriously in the global political economy. Australian Journal of Political Science 54 (4): 556-572. https://doi.org/10.1080/ 10361146.2019.1663399.

Hayden, Craig. 2012. Social media at state: Power, practice, and conceptual limits for US public diplomacy. Global Media Journal 11 (20): 1-21.

Hedling, Elsa. 2020. Storytelling in EU public diplomacy: Reputation management and recognition of success. Place Branding and Public Diplomacy 16: 143-152.

Hermann, Charles F. 1990. Changing course: When governments choose to redirect foreign policy. International Studies Quarterly 34 (1): 3-21.

Hermann, Margaret G., and Joe D. Hagan. 1998. International decision making: Leadership matters. Foreign Policy 110: 124-137.

Hernes, Helga Maria. 1987. Welfare state and woman power: Essays in state feminism. Oslo: Norweigan University Press.

Holsti, Kalevi Jaakko. 2015. Why nations realign: Foreign policy restructuring in the postwar world. London: Routledge.

Hudson, Valerie M., and Benjamin S. Day. 2019. Foreign policy analysis: Classic and contemporary theory. Lanham: Rowman \& Littlefield.

Jezierska, Katarzyna. 2021. Incredibly loud and extremely silent: Feminist foreign policy on Twitter. Cooperation and Conflict 36: 177.

Jezierska, Katarzyna, and Ann Towns. 2018. Taming feminism? The place of gender equality in the 'Progressive Sweden'brand. Place Branding and Public Diplomacy 14 (1): 55-63.

Khamis, Susie, Lawrence Ang, and Raymond Welling. 2017. Selfbranding, 'micro-celebrity' and the rise of Social Media Influencers. Celebrity Studies 8 (2): 191-208.

Madestam, Jenny, and Lena Lid Falkman. 2017. Rhetorical construction of political leadership in social media. Journal of Organizational Change Management 30 (3): 299-311.

Manor, Ilan. 2019. The digitalization of public diplomacy. New York: Springer.

Manor, Ilan, and Elad Segev. 2015. America's selfie: How the US portrays itself on its social media accounts. In Digital diplomacy, ed. Corneliu Bjola and Marcus Holmes, 103-122. London: Routledge.

Mazur, Amy G., and Dorothy McBride. Stetson. 1995. Comparative state feminism. London: Sage.

Miskimmon, Alister, Ben O'Loughlin, and Laura Roselle. 2013. Strategic narratives: Communication power and the new world order. New York: Routledge.

National Board for the Promotion of Sweden. 2017. Strategy for promoting the image of Sweden abroad - a guide. Sharingsweden.se.

Pamment, James. 2012. New public diplomacy in the 21st century: A comparative study of policy and practice. London: Routledge.

Pelling, Jon. 2015. When Doing becomes the message. In Digital diplomacy: Theory and practice, ed. Corneliu Bjola and Marcus Holmes, 164-180. London: Routledge.

Pelling, Jon. 2016. Public diplomacy in the age of networks: Midwives4all. Place Branding and Public Diplomacy 12 (2-3): 201-209.

Roden, Lee. 2017. Did Sweden's deputy PM just troll Trump with a women-only parody picture?. The Local. https://www.thelocal. se/20170203/swedens-deputy-pm-trolls-trump-in-abortion-orderimage-parody. Accessed 05 June

RosénSundström, Malena, and Ole Elgström. 2020. Praise or critique? Sweden's feminist foreign policy in the eyes of its fellow EU members. European Politics and Society 21 (4): 418-433.
Somers, Margaret R. 1994. The narrative constitution of identity: A relational and network approach. Theory and Society 23 (5): 605-649.

Standish, Reid. 2016. How Sweden is pursuing its 'feminist foreign policy' in the age of Erdogan, Putin, and Trump. Foreign Policy, 29th of July.

Stetson, Dorothy McBride., and Amy Mazur. 1995. Comparative state feminism. Thousand Oaks: Sage.

Strand, Sanna, and Katharina Kehl. 2019. "A country to fall in love with/in": Gender and sexuality in Swedish Armed Forces' marketing campaigns. International Feminist Journal of Politics 21 (2): 295-314.

Swedish Ministry for Foreign Affairs. 2018. Swedish Foreign Policy Stories. http://www.swemfa.se. Accessed 7 Nov.

Wallström, Margot. n.d. edited by @ margotwallstrom: Twitter.

Wihlborg, Elin, and Anna Norstedt. 2017. New ways and actors when diplomacy goes digital-The e-Diplomacy Campaign" Midwives4All. the 50th Hawaii International Conference on System Sciences.

Wright, Katharine AM.. 2019. Telling NATO's story of Afghanistan: Gender and the alliance's digital diplomacy. Media, War \& Confict 12 (1): 87-101.

Wright, Katharine AM., and Roberta Guerrina. 2020. Imagining the European Union: Gender and Digital Diplomacy in European External Relations. Political Studies Review. https://doi.org/10. 1177/1478929919893935.

Publisher's Note Springer Nature remains neutral with regard to jurisdictional claims in published maps and institutional affiliations.

Karin Aggestam is Professor of Political Science and Director of the Centre for Advanced Middle Eastern Studies at Lund University. Her current interdisciplinary research interests are focused on peace diplomacy, foreign policy, gender and Middle East politics. Some of her recent publications include "Political Leadership and Gendered Multilevel Games in Foreign Policy" (with J. True, International Affairs 2021), "Gendering Foreign Policy: A Comparative Framework for Analysis" (with J. True, Foreign Policy Analysis, 2020), "Theorising Feminist Foreign Policy" (with A. Bergman-Rosamond, A. Kronsell, International Relations 2019) and "The Gender Turn in Diplomacy" (with A. Towns, International Feminist Journal of Politics, 2019).

Annika Bergman Rosamond is Associate Professor at the Department of Political Science, Lund University (LU). Her research interests include feminist foreign policy, feminist security studies, global ethics as well as celebrity diplomacy and humanitarianism. She has published in journals such as Review of International Studies, Foreign Policy Analysis, Critical Military Studies, Global Society, Ethics and International Affairs, European Review of International Studies and International Feminist Journal of Politics.

Elsa Hedling is a Postdoctoral Fellow at the Department of Political Science, Lund University. She is also an Associate Research Fellow at the Swedish Institute of International Affairs in Stockholm. Her research interests concern the intersection of digital media, political communication, political sociology and international relations. She has published articles in journals such as Journal of Civil Society, Global Affairs, European Security, International Affairs and International Studies Review. 